\title{
Relationship between aerobic capacity with Birth Weight and breastfeeding patterns in children: $A$ cross-sectional study
}

\section{Relação da capacidade aeróbica com o peso ao nascer e padrões de aleitamento \\ materno em crianças: um corte transversal de escolares}

\author{
João Gabriel SILVEIRA-RODRIGUES ${ }^{1}$ iD 0000-0003-2646-5079 \\ Gabriel Araújo SOARES² (DD 0000-0003-1030-1029 \\ Joel Alves LAMOUNIER ${ }^{3}$ iD 0000-0002-0581-3217 \\ Danusa Dias SOARES1 (iD) 0000-0002-5705-8890 \\ Vinícius de Oliveira DAMASCENO ${ }^{4}$ (D) 0000-0003-0577-9204 \\ Reginaldo GONÇALVES² ID 0000-0001-6089-8375
}

A B S T R AC T

\section{Objective}

To analyze if aerobic capacity is related to Birth Weight and breastfeeding patterns in boys and girls, products of a term pregnancy and normal weight.

\footnotetext{
${ }^{1}$ Universidade Federal de Minas Gerais, Faculdade de Educação Física, Fisioterapia e Terapia Ocupacional, Departamento de Educação Física, Laboratório de Fisiologia do Exercício. Belo Horizonte, MG, Brasil.

2 Universidade Federal de Minas Gerais, Faculdade de Educação Física, Fisioterapia e Terapia Ocupacional, Departamento de Esportes, Laboratório de Avaliação da Carga. Av. Pres. Antônio Carlos, 6627, Pampulha, 31270-901, Belo Horizonte, MG, Brasil. Correspondência para/Correspondence to: R GONCCALVES. E-mail: <reginaldociclismo@hotmail.com>.

${ }^{3}$ Universidade Federal de São João Del-Rei, Faculdade de Medicina, Departamento de Medicina. São João Del-Rei, MG, Brasil.

${ }^{4}$ Universidade Federal de Pernambuco, Departamento de Educação Física, Programa de Pós-Graduação em Educação Física. Recife, PE, Brasil.

Support: Universidade Federal de Minas Gerais; FAPEMIG - APQ Process no 02341-10; Universidade de Itaúna, MG Project $\mathrm{N}^{\mathrm{0}} 016 / 2010$.

Article based on the thesis by R GONÇALVES, entitled "Identificação de limiares de circunferência de cintura, indice de massa corporal, aptidão física aeróbica e nivel de atividade física para predição do agrupamento de fatores de risco de doença cardíaca coronariana em crianças de 6 a 9 anos". Universidade Federal de Minas Gerais; 2011.
}

Como citar este artigo/How to cite this article

Silveira-Rodrigues JG, Soares GA, Lamounier JA, Soares DD, Damasceno VO, Gonçalves R. Relationship between aerobic capacity with Birth Weight and breastfeeding patterns in children: A cross-sectional study. Rev Nutr. 2018;31(5):467-77. http://dx.doi.org/10.1590/1678-98652018000500004 


\section{Methods}

A representative sample of 230 Brazilian children (6-10 years old), born at term (after 37-weeks' gestation) with normal weight (between 2.5 and $4.0 \mathrm{~kg}$ ). These children performed a Yo-Yo Test to estimate their aerobic capacity and mothers reported their children's Birth Weight and breastfeeding patterns. The Pearson correlation coefficient was used to measure the association between aerobic capacity with Birth Weight and breastfeeding patterns.

\section{Results}

We did not observe any significant associations between aerobic capacity with Birth Weight and breastfeeding time in either sexes ( $p>0.05)$.

\section{Conclusion}

These results indicate that aerobic capacity is not related with Birth Weight or breastfeeding time in children born with normal weight and gestational age, suggesting that this complex physiological parameter does not appear to be determined by intrauterine factors that dictate the Birth Weight and breastfeeding patterns in the beginning of life.

Keywords: Breastfeeding. Cardiorespiratory fitness. Child. Normal Birth Weight. Nutritional status. Term birth.

\section{RE S U M O}

\section{Objetivo}

Analisar a relação do desempenho aeróbico com o peso ao nascer e padrões de aleitamento materno na infância de crianças nascidas a termo com peso gestacional adequado.

\section{Métodos}

Duzentas e trinta crianças (6-10 anos), nascidas a termo (pós-37 semanas de gestação) e com peso normal (entre 2, 5 e 4kg) participaram do estudo. O desempenho aeróbico foi estimado pelo Yo-Yo Test. O peso ao nascer e os padrões de aleitamento materno foram relatados pelas mães das crianças mediante questionário. A correlação de Pearson foi utilizada para avaliar a relação do desempenho aeróbico com o peso ao nascer e a duração do aleitamento materno.

\section{Resultados}

Não observou-se relação do desempenho aeróbico com o peso ao nascer ou com a duração do aleitamento materno em nenhum dos sexos ( $p>0,05)$.

\section{Conclusão}

Os resultados apontam que o desempenho aeróbico não está relacionado ao peso ao nascer e nem à duração do aleitamento materno em crianças nascidas a termo e com peso normal, sugerindo que este parâmetro fisiológico parece não ser associado à fatores intrauterinos que determinam o peso no nascimento e nem ao padrão alimentar no início da vida.

Palavras-chave: Aleitamento materno. Aptidão cardiorrespiratória. Criança. Estado nutricional. Nascimento a termo.

\section{NTRO D U CTION}

Aerobic capacity or cardiopulmonary fitness is measured by Maximal Oxygen Uptake $\left(\mathrm{VO}_{2 \max }\right)$ and reflects the efficiency of all metabolic machinery in capturing, transporting and using oxygen in order to produce muscular work $[1,2]$. In a population analysis, the $\mathrm{VO}_{2 \max }$ is a general health indicator and is associated negatively with disorders of carbohydrate metabolism [1], cardiovascular diseases and relative risk of mortality [2], cardiovascular risk and obesity in children [3], and it is also directly associated with the academic performance of children and adolescents [4].

Birth Weight (BW) is considered as an indicator of the health status of newborns because it reflects the intrauterine conditions to 
which the fetus was submitted in the gestational period, representing its intrauterine growth and development [5]. Studies show that the Birth Weight is associated with several biological factors such as height, parents' body mass index, size of the newborn, gender [6] and social factors such as age, mother's level of education, number of medical visits during pregnancy, duration and number of gestations of the mother [7]. Birth Weight is also related to anthropometric measurements during childhood, being directly associated with weight, height [6] and lean mass [8]. However, their relationship with physical abilities is still uncertain. Lower muscle strength values have been shown in those born with a low Birth Weight $[9,10]$. However, when the Birth Weight was adjusted according to the infant's growth, this association was not observed [11]. Controversial findings have also been reported for aerobic capacity in which studies indicate no association between Birth Weight and aerobic capacity $[9,11]$ nor reduction of aerobic capacity when adjusting Birth Weight according to sex and age [12]. On the other hand, other studies have reported both negative $[8,13]$ and positive [6] associations between Birth Weight and aerobic capacity.

After birth, one of the recommended strategies for the promotion of a healthy infant development is through exclusive breastfeeding for at least six months [5], which may prevent the onset of future metabolic disorders [14]. It is suggested that the concentration of specific nutrients present in human milk should generally improve the health of the newborn [15] and that these improvements could also result in the improvement of all metabolic machinery involved in the extraction, transport and use of oxygen to generate muscle work.

Aerobic capacity may be influenced by early-onset eating patterns $[16,17]$, however these findings are still controversial [6]. Several studies have sought to elucidate the relationship between Birth Weight and the physical capacities of children $[8,9,10-13,18,19]$. However, in addition to the metabolic, muscular [20] and functional [18] disorders caused by Low Birth Weight (LBW), these children still appear to be less active in their free time [12], which may justify the low aerobic capacity values observed. Therefore, the presence of Birth Weight extremes in these investigations may be a confounding factor in the analysis of the association of aerobic capacity with Birth Weight due to the controversial results observed in these previous studies. In order to mitigate the effects of gestation duration and weight extremes in the association of Birth Weight with aerobic capacity, in the present study, we performed this analysis in full-term (more than 37 weeks' gestation) children with normal weight (2.5 to $4 \mathrm{~kg}$ ), which represent about $85 \%$ of world births [21].

Considering the $\mathrm{VO}_{2 \max }$ as an indicator of physical fitness and general health [1] and admitting its direct relation with the level of physical activity [12] and school performance [4], and inversely related with obesity and cardiovascular risk [3] of children, the understanding of possible factors that may be associated with this variable are useful in clinical practice and may assist in the planning of public health actions.

Therefore, the present study aims to analyze the relationship of aerobic capacity with Birth Weight and the total and exclusive time of breastfeeding in full-term, normal weight children.

\section{METHODS}

This study included boys and girls aged between 6 and 10, born after the year 2000 and $90 \%$ of these belonged to the middle and low income classes. All were students of public schools in the urban area of the city of Itaúna, in the state of Minas Gerais, Brazil, and had no limitations, medical impediments, mobility or motor skill issues that made them unable to perform the aerobic test. The research project 
was approved by the The research project was approved by the Research Ethics Committee of the Universidade Federal de Minas Gerais (UFMG, Federal University of Minas Gerais) ( $\left.n^{\circ} 0040.0 .203 .000-10\right)$ and the Universidade de Itaúna (University of Itaúna) (n012/10), in accordance with the Declaration of Helsinki. A consent form was signed by the parents prior to data collection.

From the 4,649 of the city's schoolchildren, a random sample was selected to participate in the present study. To reduce the occurrence of type II errors, we performed a pilot study with 25 students of both sexes to determine the sample size. Further details on the experimental design are described in the study by Gonçalves et al. [3]. For the calculation of the sample size, the mean and standard deviation of each variable obtained in the pilot study was used as an estimate of the population ( $\alpha=5 \%$ ). Considering a power of $80.0 \%$, the minimum sample size was 228 individuals for the variable with the highest coefficient of variation. This number was stratified in the 16 public schools of the city, maintaining proportions of age and sex. Of the 291 children initially evaluated in the physical test whose mothers answered the questionnaire, 279 presented complete data referring to the variables of the present study. Of this total, were excluded: 33 who weighed less than $2.5 \mathrm{~kg}$ at birth (13 boys, 20 girls), 10 weighing more than $4.0 \mathrm{~kg}$ ( 8 boys, 2 girls) and 6 because they were preterm babies, with a gestation period $\leq 37$ weeks ( 4 boys, 2 girls) according to wellestablished cut-off points in the literature [5]. The cuts made from the initial sample represent $11.8,3.5$ and $2.0 \%$, respectively. Finally, the analyzes conducted in this study were performed with 230 children (Table 1).

\section{Aerobic capacity}

To evaluate the aerobic capacity, it was used a Yo-Yo Test [22], validated for children and adolescents, which showed a strong correlation $(r=0.76)$ between the value estimated by the equation and the direct measurement by spirometry [23]. In this test the child should run for 20 meters in a delimited course, going back and forth, with progressive intensity until exhaustion. The pace was determined by the specific audio of the test that started at $8.5 \mathrm{~km} / \mathrm{h}$ with increments of $0.5 \mathrm{~km} / \mathrm{h}$ in each stage that lasted one minute. The test was interrupted as soon as the child was unable to keep up with two consecutive beeps even with the verbal

Table 1. Sample characteristics ( $N=230)$. Belo Horizonte (MG), Brazil, (2016).

\begin{tabular}{|c|c|c|c|c|c|c|}
\hline \multirow{2}{*}{ Characteristics } & \multicolumn{2}{|c|}{ Boys } & \multicolumn{2}{|c|}{ Girls } & \multicolumn{2}{|c|}{ Total } \\
\hline & $\mathrm{n}$ & $\%$ & $\mathrm{n}$ & $\%$ & $\mathrm{n}$ & $\%$ \\
\hline \multicolumn{7}{|l|}{ Age } \\
\hline 6 & 14 & 11.1 & 19 & 18.4 & 33 & 14.4 \\
\hline 7 & 26 & 20.6 & 12 & 11.7 & 38 & 16.6 \\
\hline 8 & 26 & 20.6 & 19 & 18.4 & 45 & 19.7 \\
\hline 9 & 29 & 23.0 & 32 & 31.1 & 61 & 26.6 \\
\hline 10 & 31 & 24.6 & 21 & 20.4 & 52 & 22.7 \\
\hline \multicolumn{7}{|c|}{ Exclusive breastfeeding time } \\
\hline Ingested infant formula & 13 & 10.3 & 13 & 12.5 & 26 & 11.3 \\
\hline $0-3$ months & 35 & 27.8 & 25 & 24.0 & 60 & 26.1 \\
\hline 4-6 months & 60 & 47.6 & 45 & 43.6 & 105 & 45.6 \\
\hline At least for 7 months & 18 & 14.3 & 21 & 19.9 & 40 & 17.0 \\
\hline
\end{tabular}


encouragement offered by the researchers to maintain the velocity stipulated at each stage. For the calculation of $\mathrm{VO}_{2 \max }$ in $\mathrm{ml} \cdot \mathrm{kg}^{-1} \cdot \mathrm{min}^{-1}$, the equation proposed by Leger \& Gadoury [24] was used: $\mathrm{VO}_{2 \max }=31.025+3.238$ (last stage velocity in $\mathrm{km} / \mathrm{h}$ ) $-3,248 \times$ (age in years) +0.1536 (final velocity $x$ age).

\section{Birth Weight and breastfeeding}

The mothers of the children participating in this study answered in person with a questionnaire for obtaining Birth Weight and total breastfeeding duration $\left(\mathrm{AM}_{\text {TOTAL }}\right)$ and whether it was exclusive $\left(A M_{\text {EXC }}\right)$ or not $\left(A M_{\text {NON-EXC }}\right)$ during the first six months of the baby's life. For the Birth Weight, the measure of precision adopted was $0.01 \mathrm{~kg}$ and for the lactation time it was one week.

\section{Anthropometry}

The body mass of the children was evaluated with a measure of precision of $0.1 \mathrm{~kg}$ and the height in the vertical Alturaexata $^{\circledR}$ (Alturaexata, São Paulo, Brazil) electronic scale with precision of $0.01 \mathrm{~cm}$, both performed in duplicate, considering the average value. The skinfolds of the brachial Triceps (TR) and the Calf $(\mathrm{CL})$ were evaluated in triplicate and the mean value was considered. For the estimation of fat percentage, we used different equations for each sex [25]. For boys: fat percentage $=0.735 \times(T R+C L)+1)$; girls: fat percentage $=0.610 \times(T R+C L)+5$. Each of the above-mentioned procedures was performed by the same evaluator and the children wore light clothes and were barefoot.

\section{Statistical analysis}

The assumptions of normality of data and homoscedasticity of variances were confirmed by the Kolmogorov-Smirnov and Levene tests, respectively, which allowed the conduction of parametric analyzes. The characteristics of both sexes are expressed as mean (95\% Confidence Interval $[\mathrm{CI}]$ ) or \pm Standard Deviation (SD) and subgroups in absolute and relative frequency. Pearson's correlation was used to evaluate the relationship between Birth Weight and duration of breastfeeding with the $\mathrm{VO}_{2 \text { max }}$. The comparison between sexes and the exclusivity of breastfeeding was analyzed by the Student's two-tailed $t$-test for independent samples. The two-way Analysis of Variance (ANOVA), followed by a Tukey post-hoc test was used to detect differences between the Birth Weight tertiles of each sex. All data were analyzed and plotted in the software Statistical Package for the Social Sciences 20.0 (SPSS Inc., Chicago, Illinois, United States). The level of significance was set at $5 \%$.

\section{RES U L T S}

Although the Birth Weight was not different between both sexes $(t=0.22, d f=228$, $p=0.83$ ), boys presented higher values of $\mathrm{VO}_{2 \max }(t=5.21, g l=228, p<0.001)$. As a result, we chose to distinguish the analyzes of the relationship between Birth Weight and $\mathrm{VO}_{2 \max }$ between the sexes. In the comparison between the sexes, boys had a lower percentage of fat $(t=2.67, d f=228, p=0.008)$ and lower fat mass compared to girls ( $t=3.12, d f=228, p=0.002)$. On the other hand, there were no differences in Body Mass Index ( $t=2.23, d f=228, p=0.22)$, height ( $t=0.98, d f=228, p=0.33)$, total body mass $(t=1.37, d f=228, p=0.17)$ and lean mass $(t=0.73, d f=228, p=0.46)$ (Table 2).

There was no relationship between the Birth Weight and $\mathrm{VO}_{2 \max }$ in both sexes (boys:0.17, $p=0.06$ and girls: $r=0.03, p=0.76$ ) (Figure 1). Similar results were found for breastfeeding, in which there was no relationship $(r<0.1$ and $p>0.35$ for both sexes) between its duration and the $\mathrm{VO}_{2 \max }$ (Figure 2).

The $A M_{\text {EXC }}$ group constituted $42 \%$ of the boys and $53 \%$ of the girls. There were also no differences in $\mathrm{VO}_{2 \max }$ (Table 3 ) between the $A M_{E X C}$ and $A M_{\text {NON-EXC }}$ groups in either sex. 
Table 2. Comparison between anthropometric and physical characteristics between boys and girls during childhood ( $N=230)$. Belo Horizonte (MG), Brazil, (2016)

\begin{tabular}{|c|c|c|c|c|}
\hline \multirow{2}{*}{ Parameters } & \multicolumn{2}{|c|}{ Boys $(n=126)$} & \multicolumn{2}{|c|}{ Girls ( $n=104)$} \\
\hline & M & $\mathrm{Cl}$ & M & $\mathrm{Cl}$ \\
\hline Birth Weight $(\mathrm{kg})$ & 3.22 & $3.16-3.29$ & 3.21 & $3.13-3.30$ \\
\hline $\mathrm{VO}_{2 \max }\left(\mathrm{ml} \cdot \mathrm{Kg}^{-1} \cdot \mathrm{min}^{-1}\right)$ & 52.00 & $51.40-52.6$ & 49.70 & $49.10-50.3^{*}$ \\
\hline Body mass index & 17.70 & $17.10-18.2$ & 17.10 & $16.40-17.8$ \\
\hline Body fat percentage (\%) & 18.80 & $17.30-20.2$ & 21.40 & $20.20-22.6^{*}$ \\
\hline Body mass (Kg) & 32.00 & $14.70-49.3$ & 30.40 & $17.90-48.3$ \\
\hline Height $(\mathrm{cm})$ & 1.34 & $1.14-1.54$ & 1.32 & $1.14-1.51$ \\
\hline Lean mass $(\mathrm{Kg})$ & 25.40 & $24.60-26.3$ & 23.40 & $22.40-24.4$ \\
\hline Fat mass $(\mathrm{Kg})$ & 6.60 & $5.70-7.4$ & 7.00 & $6.10-7.8^{*}$ \\
\hline
\end{tabular}

Note: ${ }^{*} p<0,05$ between boys and girls in the Student's $t$-test.

Mean and Confidence Interval (CI) values (95\%)

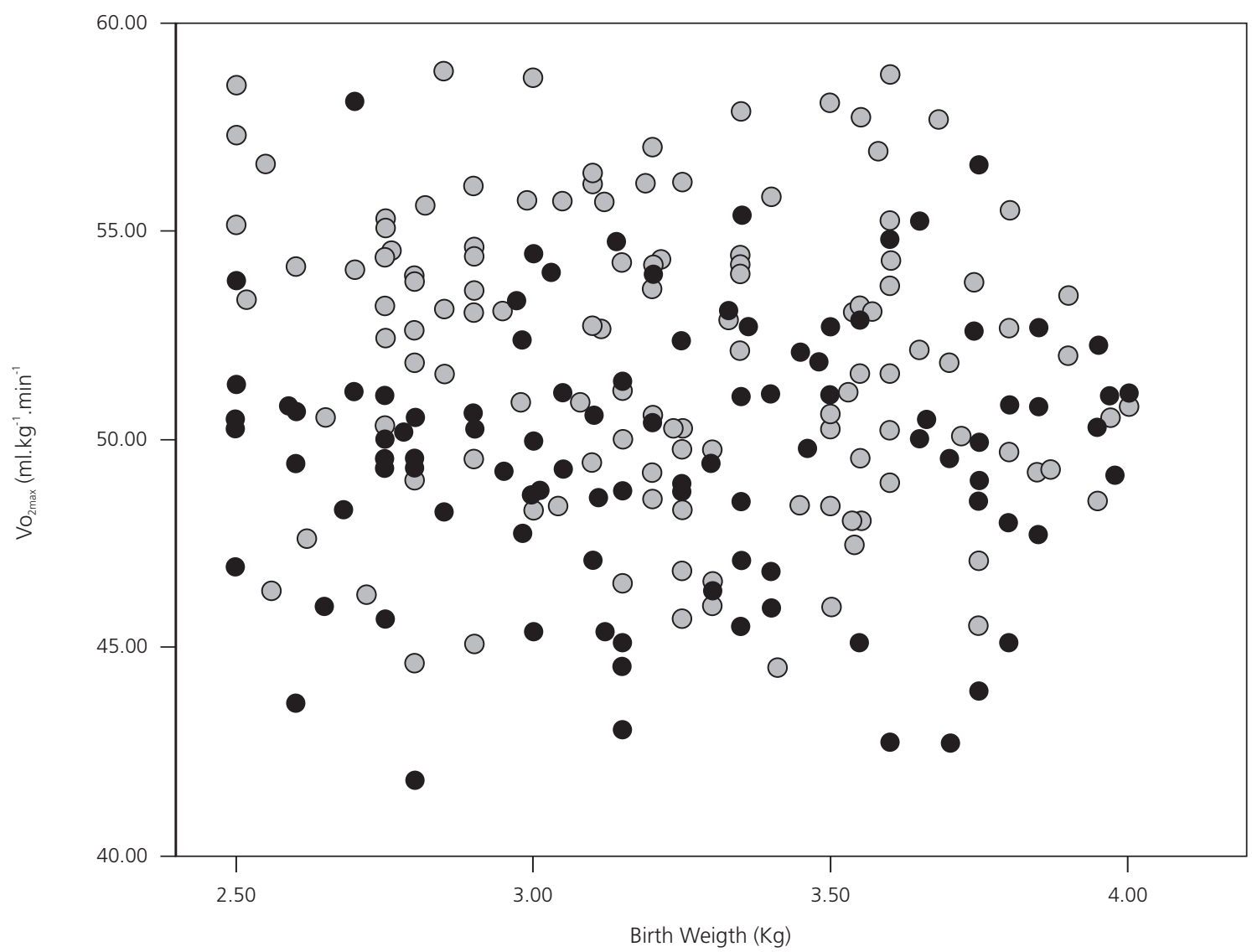

Figure 1. Pearson correlation between the $\mathrm{VO}_{2 \max }$ in childhood and Birth Weight. Belo Horizonte (MG), Brazil, (2016).

Note: Gray and black represent boys and girls, respectively. Total: 230 children (126 boys; 104 girls).

In Table 3 it was present the combined values of Birth Weight ( $1^{\text {st }}$ and $3^{\text {rd }}$ tertiles) of $\mathrm{VO}_{2 \max }$ and maternal breastfeeding (exclusive or non-exclusive).
There was an effect of sex (F:19.5; $p<0.001)$, while there was no effect of tertile ( $F: 0.61, p=0.43)$ nor tertile vs sex interaction ( $F: 1.92, p=0.25)$. 


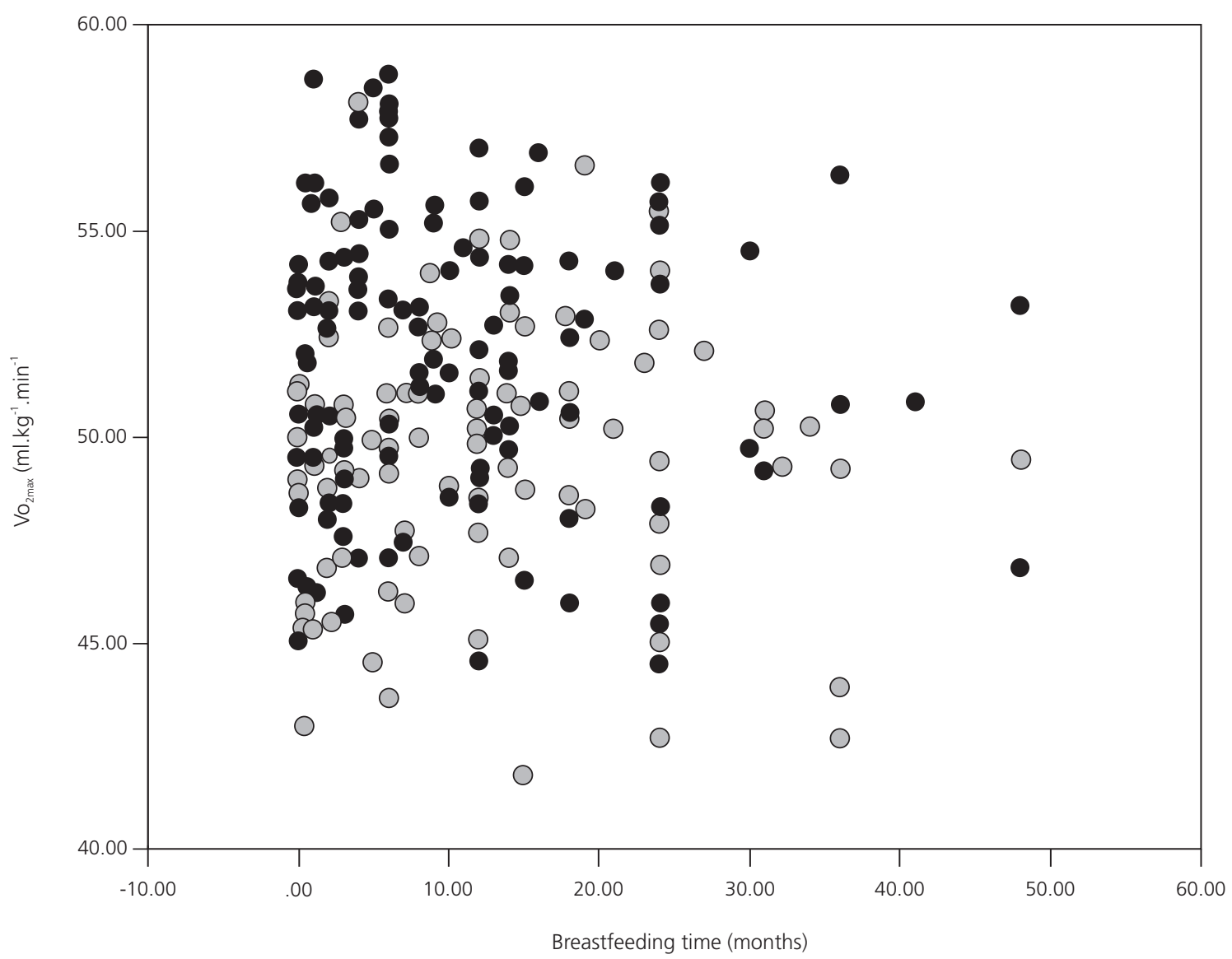

Figure 2. Pearson correlation between the $\mathrm{VO}_{2 \max }$ in childhood and breastfeeding time. Belo Horizonte (MG), Brazil, (2016). Note: Gray and black represent boys and girls, respectively. Total: 230 children (126 boys; 104 girls).

Table 3. Comparison of $\mathrm{VO}_{2 \max }$ values in childhood with Birth Weight and variables related to breastfeeding of boys and girls $(\mathrm{N}=230)$. Belo Horizonte (MG), Brazil, (2016).

\begin{tabular}{|c|c|c|c|c|c|c|}
\hline \multirow{2}{*}{ Parameters } & \multicolumn{3}{|c|}{ Boys } & \multicolumn{3}{|c|}{ Girls } \\
\hline & M & & SD & $M$ & & SD \\
\hline $1^{\text {st }}$ tertile $B W(n=42 / 34)$ & 52.8 & \pm & 3.5 & 49.7 & \pm & $3.3^{*}$ \\
\hline $3^{\text {rd }}$ tertile BW $(n=42 / 33)$ & 51.6 & \pm & 2.9 & 50.2 & \pm & $3.3^{*}$ \\
\hline $\operatorname{AM}_{\text {EXC }}(n=53 / 55)$ & 52.3 & \pm & 3.8 & 49.8 & \pm & $3.1^{* *}$ \\
\hline $\mathrm{AM}_{\text {NON-EXC }}(n=73 / 49)$ & 51.8 & \pm & 3.3 & 49.6 & \pm & $3.1^{* *}$ \\
\hline
\end{tabular}

Note: " $p<0,05$ indicates differences between the $1^{\text {st }}$ and $3^{\text {rd }}$ tertile of boys; ${ }^{* *} p<0,05$ indicates differences between the boys' $\mathrm{AM}_{\mathrm{EXC}}$ and $\mathrm{AM}_{\text {NON-EXC }}$

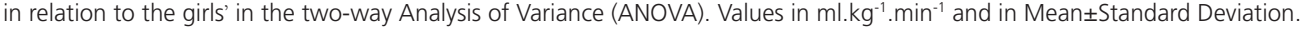
BW: Birth Weight; $\mathrm{AM}_{\mathrm{EXC}}$ : Exclusive Breastfeeding for 6 months; $\mathrm{AM}_{\text {NON-EXC }}$ : Non-Exclusive Breastfeeding for 6 months.

\section{DISCUSSIO N}

In th e present study, it was investigated the relationship between the $\mathrm{VO}_{2 \max }$ during childhood with Birth Weight and duration of breastfeeding in a representative sample of the schoolchildren of a Brazilian city, born with adequate weight and gestation time. A 
significant relationship between them was not found, highlighted by a great dispersion of the points (Figure 1), in both boys and girls. In this sense, no significant differences were found in the $\mathrm{VO}_{2 \max }$ between subjects with Birth Weight referring to the first tertile when compared to those of the third tertile, in both sexes. Similarly, no relationship was found between total duration of breastfeeding and $\mathrm{VO}_{2 \text { max }}$ nor was $\mathrm{VO}_{2 \max }$ different between those who were exclusively breastfed in the first six months of life and those who were not exclusively breastfed during this period.

Similarly to other investigations $[6,9,11,19]$, boys also presented a higher aerobic capacity than girls because of their greater amount of muscle mass and lower percentage of body fat (Table 2). Considering that the Yo-Yo Test is carried out through transporting their own body weight, the boys would take advantage of having a better body composition.

The studies that analyzed the relationship between Birth Weight and aerobic capacity presented conflicting results, which may be justified by the complexity of this physical capacity and by its different forms of evaluation. Studies that used a direct measure of oxygen consumption [18] or maximal tests for the estimation of the $\mathrm{VO}_{2 \max }[9,11]$ did not find any association between the variables. On the other hand, studies that predicted the aerobic capacity by submaximal tests show both a positive association [6] and a negative association [8]. Finally, a last study that divided the sample into four Birth Weight quartiles found that the $\mathrm{VO}_{2 \max }$ was lower in the first and fourth quartiles compared to the others, suggesting that the association between Birth Weight and $\mathrm{VO}_{2 \max }$ is an inverted-U curve [13].

Children with low Birth Weight may have pulmonary impairment and lower aerobic capacity when compared to children born with normal weight [18], although when these pulmonary issues are not present, the groups do not differ in relation to aerobic capacity [12]. The thrifty phenotype hypothesis attempts to justify cases of inadequate development of certain organs, such as the pancreas and the lung, in low Birth Weight conditions [26]. In this hypothesis it is believed that there are redistributions in the blood flow to prioritize nobler tissues, such as the brain [26]. Considering previous literature data and the results of the present study, it is possible that this hypothesis explains well the physiological impairments in individuals with low Birth Weight as reported in the studies by Clemm et al. [12] and Smith et al. [18]. However, in the present study only individuals whose Birth Weight and gestational age are within a suitable range were analyzed and, under these conditions, the theory apparently is not applicable. Thus, it was hypothesized that the evaluated children reached full muscular and cardiopulmonary system development, which are determinants of aerobic capacity, and that the intrauterine development, or simply the Birth Weight per se does not influence the aerobic capacity in this case.

Studies analyzing the relationship between breastfeeding and aerobic capacity present conflicting findings, indicating that these variables may be related $[16,17]$ or unrelated [6]. European infants who were exclusively breastfed for more than three months exhibit a higher $\mathrm{VO}_{2 \max }$ when compared to children who were breastfed for a shorter period or not breastfed at all [16] and Iranian children who were breastfed for more than six months also showed higher $\mathrm{VO}_{2 \max }$ levels than those who were breastfed for less than six months and those who have ingested industrialized infant formulas [17]. It is reported in the literature that the nutrients present in human milk could improve the newborn's health [15] and it was hypothesized in this study that the duration or exclusivity of breastfeeding could influence aerobic capacity. Contrary to our initial hypothesis, no differences were observed in $\mathrm{VO}_{2 \max }$ levels between the group that was breastfed exclusively with breast milk in the first six months and the group not 
exclusively breastfed during the same period. Corroborating these findings, the duration of lactation also did not influence aerobic capacity [6]. Thus, it is speculated that malnutrition or insufficient dietary intake, a condition more present in underdeveloped countries compared to developed countries, may be more determinant in attenuating the aerobic capacity than breastfeeding patterns themselves.

The great divergence between previous results in the literature can also occur due to the nature of $\mathrm{VO}_{2 \max }$ levels, which are influenced by modifiable factors such as the habitual physical activity level, medical history and obesity, and also by non-modifiable factors such as age, sex and genotype [2] representing a parameter with great variability. In addition, $\mathrm{VO}_{2 \max }$ levels have heterogeneous responses as a function of aerobic training, showing differences of up to $100 \%$ among individuals [27] and mean increases of $15 \%$ among populations, although increases of up to $47 \%$ can be observed in some families [28]. Thus, VO2max levels appear to be strongly influenced by hereditary components that influence all or part of the system involved in the uptake, transport and use of oxygen. In this way, it was pointed out that the sample of this study differs from the other investigations carried out so far mainly by the continent of research, which was mostly concentrated in the European continent (Northern Ireland, England, Spain, Norway, Belgium and the Netherlands) who share a greater common ancestry than the Latin American population.

The Birth Weight is also influenced by several other factors, such as socioeconomic, genetic [29], familial [7], and childhood growth aspects, which may modify the association between the $\mathrm{VO}_{2 \max }$ and Birth Weight, considering children born with a normal Birth Weight and average or accelerated growth rates, or also those with low Birth Weight and average growth rates presented higher aerobic performance than those with low Birth Weight and accelerated growth rates [11]. Thus, it is possible to speculate that, in developed countries, a low Birth Weight is less related to socioeconomic factors and more related to genetic factors such as parental height. This context is different from that observed in underdeveloped and developing countries where socioeconomic aspects may justify the higher prevalence of children with low Birth Weight, such as when comparing South America with Europe [21]. Breastfeeding patterns are also different in distinct countries and cultures and depend on socio-cultural support for their success [30], which may justify controversial results found among different studies. Therefore, considering the various factors involved in $\mathrm{VO}_{2 \text { max }}$ in Birth Weight and in breastfeeding patterns of children, it is concluded that the present cross-sectional study, performed in individuals with adequate Birth Weight and gestational age, contributes to the current body of scientific knowledge about population and to assist in the planning of public health actions and in the clinical practice of professionals dealing with children and adolescents.

A limitation of the study is the fact that Birth Weight and breastfeeding patterns were reported through a questionnaire answered by the children's mothers, a fact that may be less accurate when compared to the medical chart of newborn babies. Studies with longitudinal characteristics that allow individuals to be followed for a longer period of time are suggested in order to elucidate this relationship between the variables related to physical fitness and Birth Weight not only during childhood but also in the prolongation of the individual's life course. Studies investigating genetic polymorphisms in infants born at the lower and upper Birth Weight limits are also encouraged in order to elucidate the different associations observed in the populations.

\section{CONCLUSION}

The findings contained in this study indicate that the aerobic capacity, expressed by 
the levels of $\mathrm{VO}_{2 \text { max }^{\prime}}$ is not related to the Birth Weight and the time of breastfeeding in fullterm, normal weight-born children. Thus, given the complexity of $\mathrm{VO}_{2 \text { max }}$ it does not appear to be determined by intrauterine factors nor by factors related to breastfeeding habits in the conditions of full-term and adequate Birth Weight conditions.

\section{CONTRIBUTORS}

R GONÇALVES, JA LAMOUNIER and VO DAMASCENO collaborated with the study conception and design; JG SILVEIRA-RODRIGUES, VO DAMASCE$N O$ and $R$ GONÇALVES participated with data collection; JG SILVEIRA-RODRIGUES, GA SOARES, VO DAMASCENO and R GONÇALVES elaborated data interpretation and statistical analysis. All the authors participated on the article preparation.

\section{REFERENCES}

1. Koch LG, Britton SL. Aerobic metabolism underlies complexity and capacity. J Physiol. 2008;586(1):83-95. http://dx.doi.org/10.1113/ jphysiol.2007.144709

2. Lee DC, Artero EG, Sui X, Blair SN. Review: Mortality trends in the general population: The importance of cardiorespiratory fitness. J Psychopharmacol. 2010;24(Suppl.4):27-35. http:// dx.doi.org/10.1177/1359786810382057

3. Gonçalves $R$, Szmuchrowski LA, Damasceno VO, Medeiros MLD, Couto BP, Lamounier JA. Association of body mass index and aerobic physical fitness with cardiovascular risk factors in children. Rev Paul Pediatr. 2014;32(3):208-14. http://dx.doi.org/10.1590/0103-0582201432310

4. Santana CC, Azevedo LB, Cattuzzo MT, Hill JO, Andrade LP, Prado WL. Physical fitness and academic performance in youth: A systematic review. Scan J Med Sci Sports. 2017;27(6):579-603. http://dx.doi.org/10.1113/jphysiol.2007.144709

5. World Health Organization. Promoting optimal fetal development: Report of a technical consultation. Geneva: WHO; 2006.

6. Lawlor D, Cooper AR, Bain C, Smith GD, Irwin A, Riddoch $C$, et al. Associations of birth size and duration of breast feeding with cardiorespiratory fitness in childhood: Findings from the Avon Longitudinal Study of Parents and Children
(ALSPAC). Eur J Epidemiol. 2008;23(6):411-22. http://dx.doi.org/10.1007/s10654-008-9259-x

7. Gouveia N, Bremner AS, Novaes HMD. Association between ambient air pollution and Birth Weight in São Paulo, Brazil. J Epidemiol Community Health. 2004;58(1):11-17. http://dx.doi.org/10.1136/jech. 58.1 .11

8. Santos MAM, Almeida MB, Castro RM, Katzmarzyk PT, Maia JAR, Leandro CG. Birthweight, body composition, and motor performance in 7-to 10-year-old children. Dev Med Child Neurol. 2015;57(5):470-5. http://dx.doi.org/10.1111/dmcn. 12664

9. Ortega FB, Labayen I, Ruiz JR, Martin-Matillas M, Vicente-Rodríguez G, Redondo C, et al. Are muscular and cardiovascular fitness partially programmed at birth? Role of body composition. J Pediatr. 2009;154(1):61-6. http://dx.doi.org/10.10 16/j.jpeds.2008.07.041

10. Tchamo M, Santos MAM, Almeida MBD, Leandro CG. Physical fitness and Birth Weight in young men from Maputo City, Mozambique. Rev Bras Med Esporte. 2016;22(1):66-70. http://dx.doi. org/10.1590/1517-869220162201147126

11. Van Deutekom AW, Chinapaw MJM, Vrijkotte TGM, Gemke RJBJ. The association of Birth Weight and infant growth with physical fitness at 8-9 years of age: The ABCD study. Int J Obes. 2015:39(4):593-600. http://dx.doi.org/10.1038/ijo. 2014.204

12. Clemm H, Røksund O, Thorsen E, Eide GE, Markestad T, Halvorsen T. Aerobic capacity and exercise performance in young people born extremely preterm. Pediatrics. 2012;129(1):97-105. http://dx.doi.org/10.1542/peds.2011-0326

13. Touwslager RN, Gielen M, Tan FE, Mulder AL, Gerver WJ, Zimmermann LJ, et al. Genetic, maternal and placental factors in the association between Birth Weight and physical fitness: A longitudinal twin study. Plos One. 2013;8(10):e76423. http:// dx.doi.org/10.1371/journal.pone.0076423

14. Horta B, Victora C. Long-term effects of breastfeeding: A systematic review. Geneva: World Health Organization; 2013.

15. Gartner LM, Morton J, Lawrence RA, Naylor AJ, O'Hare D, Schanler RJ, et al. Breastfeeding and the use of human milk. Pediatrics. 2005;115(2):496-506. http://dx.doi.org/10.1542/peds.2004-2491

16. Labayen I, Ruiz JR, Ortega FB, Loit HM, Harro J, Villa $\mathrm{l}$, et al. Exclusive breastfeeding duration and cardiorespiratory fitness in children and adolescents. Am J Clin Nutr. 2012;95(2):498-505. http://dx.doi.org/10.3945/ajcn.111.023838 
17. Vafa M, Heshmati J, Sadeghi H, Shidfar F, Namazi $\mathrm{N}$, Baradaran $\mathrm{H}$, et al. Is exclusive breastfeeding and its duration related to cardio respiratory fitness in childhood? J Matern Fetal Neonatal Med. 2016;29(3):461-5. http://dx.doi.org/10.310 9/14767058.2015.1004052

18. Smith LJ, Van Asperen PP, McKay KO, Selvadurai $H$, Fitzgerald DA. Reduced exercise capacity in children born very preterm. Pediatrics. 2008;122(2):287-93. http://dx.doi.org/10.1542/peds. 2007-3657

19. Aoyama T, Tsushita K, Miyatake N, Numata T, Miyachi M, Tabata l, et al. Does cardiorespiratory fitness modify the association between Birth Weight and insulin resistance in adult life? Plos One. 2013;8(9):e73967. http://dx.doi. org/10.1371/journal.pone.0073967

20. Jensen CB, Storgaard $H$, Madsbad S, Richter EA, Vaag AA. Altered skeletal muscle fiber composition and size precede whole-body insulin resistance in young men with low Birth Weight. J Clin Endocrinol Metab. 2007;92(4):1530-4. http:// dx.doi.org/10.1210/jc.2006-2360

21. Wardlaw, TM. Low birthweight: Country, regional and global estimates. New York: Unicef; 2004.

22. Leger L, Lambert J, Goulet A, Rowan C, Dinelle Y. Capacité aérobie des Québécois de 6 a17 ans-Test navette de 20 metres avec paliers de 1 minute. Can J Appl Sport Sci. 1984;9(2):64-9.

23. Van Mechelen W, Hlobil $H$, Kemper HCG. Validation of two running tests as estimates of maximal aerobic power in children. Eur J Appl Physiol Occup Physiol. 1986;55(5):503-6.
24. Leger L, Gadoury C. Validity of the $20 \mathrm{~m}$ shuttle run test with 1 min stages to predict VO2max in adults. Can J Sport Sci. 1989;14(1):21-6.

25. Slaughter MH, Lohman TG, Boileau R, Horswill CA, Stillman RJ, Van Loan MD, et al. Skinfold equations for estimation of body fatness in children and youth. Hum Biol. 1988,60(5):709-23.

26. Nicholas HC, Barker DJP. The thrifty phenotype hypothesis. Brit Med Bull. 2001;60(1):5-20. http:// dx.doi.org/10.1007/s00125-012-2589-y

27. Bouchard C, Rankinen T. Individual differences in response to regular physical activity. Med Sci Sports Exerc. 2001;33(6):S446-51. http://dx.doi. org/10.1097/00005768-200106001-00013

28. Bouchard C, An P, Rice T, Skinner JS, Wilmore $\mathrm{JH}$, Gagnon J, et al. Familial aggregation of $\mathrm{VO}_{2 \max }$ response to exercise training: Results from the heritage family study. J Appl Physiol. 1999;87(3):1003-8. http://dx.doi.org/10.1249/ MSS.0b013e3181935a11

29. Freathy RM, Weedon MN, Bennett A, Hyppönen E, Relton CL, Knight B, et al. Type 2 diabetes TCF7L2 risk genotypes alter Birth Weight: A study of 24,053 individuals. Am J Hum Gen. 2007;80(6):1150-61. http://dx.doi.org/10.1086/518517

30. Shakya P, Kunieda MK, Koyama M, Rai SS, Miyaguchi M, Dhakal S, et al. Effectiveness of community-based peer support for mothers to improve their breastfeeding practices: A systematic review and meta-analysis. Plos One. 2017;12(5):e0177434. https://dx.doi.org/10.13 71/journal.pone.0177434

Received: April 11, 2018

Final version: September 27, 2018

Approved: November 23, 2018 